\section{Does Sand Application to Soil Surface Benefit Cranberry Production?}

\author{
Bernadine C. Strik ${ }^{1}$ \\ Department of Horticulture, Oregon State University, ALS 4017, Corvallis, \\ OR $97331-7304$
}

Arthur P. Poole ${ }^{2}$

Coos County Extension, Coos County Coquille Annex, 290 North Central, Coquille, OR 97423

Additional index words. yield components, pruning, pest management, Vaccinium macrocarpon

\begin{abstract}
The effect of sand application to 'Stevens' cranberry (Vaccinium macrocarpon Ait.) was studied for 3 years in a 24-year-old (site 1) and an 8-year-old (site 2) commercial planting. Treatments in Apr. 1991 consisted of a onetime sand application of $1.3 \mathrm{or} 2.5 \mathrm{~cm}$ on the surface of the cranberry bed and a nonsanded control. Yield component data were collected in Fall 1991 through 1993. In 1991, $2.5 \mathrm{~cm}$ of sand reduced yield 50\% at site 2 compared to the nonsanded control. At site 1 , the $2.5-\mathrm{cm}$ sand depth did not reduce yield, while the $1.3-\mathrm{cm}$-deep application improved yield $18 \%$ compared to the control. The year after sanding (1992), yields equalized across all treatments at both sites. In 1993, there was no significant difference in yield for treatments at site 1 . At site 2 , however, heavy sanding reduced yield $63 \%$ compared to $1.3 \mathrm{~cm}$ of sand. Our work suggests that heavy sanding is not recommended for 'Stevens' cranberry beds in Oregon.
\end{abstract}

Sanding was one of the first cultural practices to be used in cranberry production. This practice originated from an observation in 1810 by Henry Hall in Cape Cod, Mass., who noted that sand blown onto his wild cranberry vines improved growth (Eck, 1990).

Sand application to peat cranberry bogs has since become a common practice in eastern and north-central United States production regions to rejuvenate old plantings and to reduce growth on excessively vegetative sites. In these regions, sand is surface-applied to ice used for winter protection, and settles down onto the plants and soil surface when ice melts in the spring.

A layer of sand varying in depth from 0.6 to $2.5 \mathrm{~cm}$ typically is applied to cranberry beds every 3 to 4 years. If vine growth is particularly heavy, as much as $5 \mathrm{~cm}$ of sand may be applied (Cross and DeMoranville, 1969; Eck, 1990). While there are many benefits to growth and yield attributed to sanding, there is little research to substantiate these effects. The primary benefit of the sand is to cover old runners and stimulate their rooting (Cross and DeMoranville, 1969). Eck (1990) mentions

Received for publication 23 May 1994. Accepted for publication 7 Oct. 1994. Oregon Agricultural Experiment Station Technical Paper 10,500. We gratefully acknowledge the technical assistance of Dawna Jackson and the support of the Oregon Cranberry Growers' Association and Ocean Spray Cranberries. The cost of publishing this paper was defrayed in part by the payment of page charges. Under postal regulations, this paper therefore must be hereby marked advertisement solely to indicate this fact.

${ }^{1}$ Associate Professor.

${ }^{2}$ Area Horticultural Extension Agent. that at least $2.5 \mathrm{~cm}$ of sand is required to promote runner rooting. New roots could revitalize the plants and stimulate new upright formation (Dana, 1990).

Other benefits of sanding include a potential reduction in populations of cranberry tip worm and girdler (Franklin, 1913; Roper, 1994; Tomlinson, 1937), improved soil aeration/ drainage (Cross and DeMoranville, 1969; Tomlinson, 1937), and greater frost protection (Cross and DeMoranville, 1969). Although some researchers claim that sanding may improve weed management (Tomlinson, 1937), the practice may introduce weed seeds (Cross and DeMoranville, 1969). Beneficial effects of sanding on weed control may occur in later growing seasons when increased vine vigor effectively crowds out weed species (Cross and DeMoranville, 1969; Eck, 1990).

Cross and DeMoranville (1969) were of the opinion that sanding also may benefit yield because a clean, white layer of sand may increase the amount of reflected light, thus contributing to increased cranberry vine photosynthesis.

Franklin (1916), in comparing nonsanded (for 6 years) plots in Massachusetts to those that had been sanded at various frequencies, reported no significant yield effect. However, 1 year later he reported that the control plots (not sanded for 7 years) yielded less than sanded plots (Franklin, 1917). Beckwith (1941) reported that research in New Jersey in 1927 indicated that cranberry vines sanded 2 years before yield was measured yielded twice the crop and those sanded 3 years before bore three times the crop as the nonsanded plot. However, Beckwith (1941) mentioned that yield effects from sanding were variable in New Jersey.
Yield benefits have been attributed to improved drainage on peat bogs (Beckwith, 1941). Sand may be of less benefit when applied to nonpeat cranberry beds common in the Pacific Northwest.

The objective of our study was to determine the effects of sand application on yield components of 'Stevens' cranberry in Oregon.

\section{Materials and Methods}

'Stevens' cranberry was studied at two grower cooperator sites, an 8-year-old and a 24-year-old planting (bed) located on the southern Oregon coast near Sixes and Bandon, respectively. Neither bed had been previously sanded. In Apr. 1991, three treatments were established at each site: a nonsanded control (0 $\mathrm{cm}$ ), and sand 1.3 or $2.5 \mathrm{~cm}$ deep. Plots were $1.8 \times 1.8 \mathrm{~m}$ arranged in a completely random design with five replicates. Sand was applied gently by hand to minimize vine damage. After application, sand matted on the surface of leaves was vibrated off with fingertips to lower depths within the canopy. On-site local sand, excavated from the subsurface of raised marine terraces, was applied. Sand weight percentages were $6 \%$ coarse $(0.5$ to $1.0 \mathrm{~mm})$ : $34 \%$ medium $(0.25$ to $0.5 \mathrm{~mm}): 57 \%$ fine $(0.1$ to $0.25 \mathrm{~mm}): 2 \%$ very fine $(0.05$ to $0.1 \mathrm{~mm})$ at the 24-year-old site and 5\% medium : $94 \%$ fine : $1 \%$ very fine at the 8 -year-old site. No additional sand was applied during the experiment.

Light reflectance from the surface of the cranberry bed was measured on a sunny day from 12:00 to 14:00 HR in July 1991 using a point quantum sensor (LI-188B; LI-COR, Lincoln, Neb.) inverted $2 \mathrm{~cm}$ above the plant canopy.

In Fall 1991, 1992, and 1993, just before commercial harvest, two $0.03-\mathrm{m}^{2}$ samples were collected from each treatment plot. The following yield component data were collected: total sample fresh weight; number of nonfruiting uprights $\left(\mathrm{U}_{\mathrm{N}}\right)$; number of fruiting uprights $\left(\mathrm{U}_{\mathrm{F}}\right)$; average length of currentseason's growth of $U_{N}$ and $U_{F}$ (mean of 25 uprights randomly selected from sample); number of runners and runner weight; number of flowers (from counting persistent pedicels); number of nonmarketable and marketable berries; yield; and total anthocyanin content of fruit, determined by extracting a 100-g sample of fruit with $95 \%$ ethanol (Sapers and Hargrave, 1987). Average berry weight, estimated yield $\left(\mathrm{t} \cdot h \mathrm{a}^{-1}\right)$, percent fruit set, and percent $\mathrm{U}_{\mathrm{F}}$ were calculated from the raw data. In each sanded plot, a plug $\left(20-\mathrm{cm}^{2}\right)$ was collected to measure root growth in the new sand layer. Roots in the sand layer were separated from stem tissue and sand and dried to a constant weight at $70 \mathrm{C}$. Percent weed coverage was estimated for each plot.

Data were tested by analysis of variance for a factorial design (SAS Institute, 1988) and means compared by the Waller-Duncan $\mathrm{k}$ ratio test. However, many yield component data were lost in 1992 due to refrigerator failure during plant storage. 


\section{Results}

There was a significant year $\times$ site $\times$ treatment interaction for yield and a year $\times$ site interaction for all variables.

The sites differed in yield, independent of sanding treatment, presumably due to planting age, cultural management, and microclimate effects. The 24-year-old bed (site 1) had a 3-

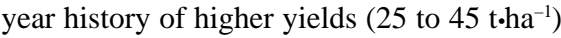
than the 8-year-old site (site 2; 7 to $20 \mathrm{t}^{\circ} \mathrm{ha}^{-1}$ ) before the start of the experiment. In general, percent fruit set was lower at site 2 during the course of the experiment ( $12 \%$ to $37 \%$ compared to $43 \%$ to $51 \%$ at site $1 ; P \leq 0.05$ ), probably a result of its proximity $(<1 \mathrm{~km})$ to the Pacific Ocean and exposure to desiccating winds.

1991. In 1991, the year of the sanding treatment, yield at site 1 was much higher than at site $2(P \leq 0.05$; Table 1$)$. The lower yield at site 2 was the result of a lower percent fruit set (data not shown), fewer marketable berries, and fewer uprights (Table 1). The $2.5-\mathrm{cm}$ sand depth reduced yield $50 \%$ at site 2 compared to the 0 - and $1.3-\mathrm{cm}$ sand depths (Table 1 ). Lower yield from deep sanding was the result of fewer marketable berries (Table 1) and a lower percent fruit set (data not shown). At site 1, the $2.5-\mathrm{cm}$ sand depth did not reduce yield, but the $1.3-\mathrm{cm}$ application improved yield $27 \%$ compared to the $2.5-\mathrm{cm}$ depth (Table 1 ).

In 1991, sand application increased runner weight at site 2 and tended to do the same at site 1 (Table 1). Our data for root weight accumulated in the new sand layer in the 6 months since application (Table 1) agrees with earlier research that application of sand stimulates root growth (Cross and DeMoranville, 1969; Dana, 1990; Eck, 1990; Tomlinson, 1937). However, there was no effect of sanding reducing upright length (Table 1) in our study, as speculated by Cross and DeMoranville (1969). In fact, sand application increased the length of nonfruiting uprights at both sites in 1992 and at site 1 in 1993 (Table 1). Sanding did not affect light reflectance in this study (data not shown), indicating that this factor may not be involved in increased yields after sand application through an increase in photosynthesis (Cross and DeMoranville, 1969; Roper, 1994).

1992. Yields were high in 1992. Oregon cranberry growers had record high crops. In this year, yields equalized across all treatments at both sites (Table 1). Runner weight was much higher at site $2(P \leq 0.05$; Table 1$)$ and percent fruiting uprights was high at both sites in 1992 (data not shown).

1993. In 1993, yields were significantly lower than in $1992(P \leq 0.05$; Table 1$)$. This reduction may support the sometimes observed biennial bearing of cranberry beds, but also was related to wet and cloudy weather during bloom (data not shown). Individual cranberry uprights can bear biennially (Roper et al., 1993; Strik et al., 1991).

In 1993, cranberry yield at site 2 was lower with $2.5 \mathrm{~cm}$ than with $1.3 \mathrm{~cm}$ of sand (Table 1 ) because of fewer marketable berries (Table 1) and a trend of reduced fruit set ( $15 \%$ compared to $30 \%$ ).

Runner weight was higher at site 2 , as it was in 1991 and $1992(P \leq 0.05$; Table 1$)$, although this appeared to be independent of sanding treatments.

There was no significant effect of sanding on percent weed coverage, percent fruiting uprights, berry weight, or berry anthocyanin content in any year (data not shown). However, significantly more nonfruitful uprights were produced in the third year at site 1 in response to sanding, potentially increasing future yields (Table 1).

\section{Discussion}

Cranberry yields in this study varied greatly from year to year; for example, the control plots at site 1 showed a 17 to 64 t.ha ${ }^{-1}$ range in yield (Table 1). However, from our study, we can conclude that heavy sanding $(2.5 \mathrm{~cm})$ may be detrimental to yield. Cumulative yield indicated that, relative to the nonsanded control plots, light sanding $(1.3 \mathrm{~cm})$ increased yield $4 \%$ at site 1 and had no effect at site 2 , whereas heavy sanding $(2.5 \mathrm{~cm})$ reduced yield $6 \%$ at site 1 and $14 \%$ at site 2 .

If sanding has a similar effect on cranberries as pruning, then perhaps light sanding (1.3 $\mathrm{cm}$ ) every 3 to 4 years may benefit yields in Oregon. These findings are similar to those showing that alternate-year pruning benefits yield in cranberry (Strik and Poole, 1992). In a summary of research presented by Daven-

Table 1. Effect of sanding treatments in 1991 on yield components of 'Stevens' cranberry in 1991-93 at two sites, a 24-year-old bed (site 1) and an 8-year-old bed (site 2).

\begin{tabular}{|c|c|c|c|c|c|c|c|}
\hline \multirow{2}{*}{$\begin{array}{l}\text { Year, site, and } \\
\text { sand depth }(\mathrm{cm})\end{array}$} & \multirow{2}{*}{$\begin{array}{c}\text { Runner } \mathrm{wt}^{2} \\
\left(\mathrm{~g} \cdot \mathrm{m}^{-2}\right)\end{array}$} & \multirow{2}{*}{$\begin{array}{l}\text { Length }^{y, x} \\
U_{N}(m m)\end{array}$} & \multicolumn{2}{|c|}{ Upright no. ${ }^{z, x}$} & \multirow{2}{*}{$\begin{array}{c}\text { Root dry wt } \\
\left(\mathrm{kg} \cdot \mathrm{m}^{-2}\right)\end{array}$} & \multirow{2}{*}{$\begin{array}{c}\text { No. marketable } \\
\text { berries }^{z}\end{array}$} & \multirow{2}{*}{$\begin{array}{c}\text { Est. yield } \\
\left(\text { t.ha }{ }^{-1}\right)\end{array}$} \\
\hline & & & $\mathrm{U}_{\mathrm{N}}$ & $\mathrm{U}_{\mathrm{F}}$ & & & \\
\hline \multicolumn{8}{|l|}{1991} \\
\hline \multicolumn{8}{|l|}{ Site 1} \\
\hline 0 & 3.7 & 59 & 258 & 158 & $\mathrm{NA}^{\mathrm{w}}$ & 198 & $44 \mathrm{ab}^{\mathrm{v}}$ \\
\hline 1.3 & 8.7 & 71 & 223 & 165 & 0.28 & 224 & $52 \mathrm{a}$ \\
\hline 2.5 & 11.3 & 74 & 297 & 146 & 0.26 & 171 & $41 \mathrm{~b}$ \\
\hline \multicolumn{8}{|l|}{ Site 2} \\
\hline 0 & $6.7 \mathrm{a}$ & 52 & 69 & 77 & NA & $50 \mathrm{a}$ & $12 \mathrm{~A}$ \\
\hline 1.3 & $8.0 \mathrm{ab}$ & 43 & 113 & 89 & 0.27 & $52 \mathrm{a}$ & $12 \mathrm{~A}$ \\
\hline 2.5 & $16.7 \mathrm{~b}$ & 59 & 98 & 82 & 0.41 & $28 \mathrm{~b}$ & $6 \mathrm{~B}$ \\
\hline \multicolumn{8}{|l|}{1992} \\
\hline \multicolumn{8}{|l|}{ Site 1} \\
\hline 0 & $--^{u}$ & $38 \mathrm{a}$ & 64 & $114 \mathrm{a}$ & NA & --- & 64 \\
\hline 1.3 & 3.3 & $42 \mathrm{a}$ & 93 & $144 \mathrm{ab}$ & 0.34 & --- & 65 \\
\hline 2.5 & 2.9 & $61 \mathrm{~b}$ & 166 & $187 \mathrm{~b}$ & 0.37 & --- & 65 \\
\hline \multicolumn{8}{|l|}{1992} \\
\hline \multicolumn{8}{|l|}{ Site 2} \\
\hline 0 & 11.3 & $37 \mathrm{a}$ & 72 & 135 & NA & --- & 53 \\
\hline 1.3 & 9.0 & $42 \mathrm{ab}$ & 75 & 136 & 0.33 & --- & 51 \\
\hline 2.5 & 15.0 & $52 \mathrm{~b}$ & 89 & 156 & 0.53 & --- & 52 \\
\hline \multicolumn{8}{|l|}{1993} \\
\hline \multicolumn{8}{|l|}{ Site 1} \\
\hline 0 & 4.0 & $59 \mathrm{a}$ & $227 \mathrm{a}$ & 66 & NA & 46 & 17 \\
\hline 1.3 & 5.0 & $76 \mathrm{~b}$ & $312 \mathrm{~b}$ & 65 & 0.32 & 49 & 13 \\
\hline 2.5 & 4.0 & $73 \mathrm{~b}$ & $308 \mathrm{~b}$ & 70 & 0.43 & 54 & 12 \\
\hline \multicolumn{8}{|l|}{ Site 2} \\
\hline 0 & 19.3 & 58 & 178 & 61 & NA & $36 \mathrm{a}$ & $6 \mathrm{ab}$ \\
\hline 1.3 & 14.4 & 55 & 202 & 67 & 0.44 & $36 \mathrm{a}$ & $8 \mathrm{a}$ \\
\hline 2.5 & 21.4 & 59 & 192 & 61 & 0.42 & $18 \mathrm{~b}$ & $3 \mathrm{~b}$ \\
\hline
\end{tabular}

${ }^{2}$ Sample area $=0.06 \mathrm{~m}^{2}$.

${ }^{y}$ Average of 25 randomly selected uprights.

${ }^{x} U_{N}=$ number of nonfruiting uprights; $U_{F}=$ number of fruiting uprights.

${ }^{\mathrm{w}} \mathrm{NA}=$ not applicable.

"Mean separation in columns within year and site by Waller-Duncan test, $P=0.05$ (lowercase letters) or 0.01 (uppercase letters).

"Missing data. 
port (1994), L. Kummer showed a 9\%, 11\%, and $22 \%$ increase in yield of 'Searles' in Wisconsin over 3 years after light sanding, light pruning, and sanding plus pruning treatments, respectively.

The only other documented work on sanding effects on yield indicated variable results and a decline in production on nonsanded plots only after 7 years (Franklin, 1917). We speculate that effects of sanding on productivity may be variable for two reasons: planting age and bed construction. A deep application of sand may smother young vines. Also, most positive effects of sanding have been observed in peat cranberry bogs. This effect may be due to improved aeration or drainage (Beckwith, 1941; Cross and DeMoranville, 1969) and possibly less frost damage (Cross and DeMoranville, 1969). As might be expected, the effect of sanding would be less on beds already predominantly consisting of sand, such as those found in Oregon.

Although sanding may be of benefit to rejuvenate an old cranberry planting (Eck,
1990), to reestablish weak or uneven areas of a bed (Beckwith, 1941), or for some measure of pest management (Beckwith, 1941; Cross and DeMoranville, 1969; Eck, 1990; Tomlinson, 1937), applications of $>1.3 \mathrm{~cm}$ of sand to productive, nonpeat 'Stevens' beds may reduce yield.

\section{Literature Cited}

Beckwith, C.S. 1941. The sanding of cranberry bogs, p. 10-13. In: Proc. 71st Annu. Mtg., Amer. Cranberry Growers' Assn., Chatsworth, N.J.

Cross, C.E. and I.E. DeMoranville. 1969. Resanding of Massachusetts cranberry bogs. Univ. of Massachusetts Coop. Ext. Serv., Publ. 36. p. 10.

Dana, M.N. 1990. Cranberry management, p. 334 362. In: G.J. Galletta and D.G. Himelrick (eds.). Small fruit crop management. Prentice Hall, Englewood Cliffs, N.J.

Davenport, J. 1994. Practical practices. Harvest 16:10.

Eck, P. 1990. The American cranberry. Rutgers Univ. Press, New Brunswick, N.J. p. 223-225.

Franklin, H.J. 1913. The cranberry girdler. 25th Annu. Rpt., Massachusetts Agr. Expt. Sta., 1912. p. 27-28.
Franklin, H.J. 1916. Report of the cranberry substation for 1915. Massachusetts Expt. Sta. Bul. 168. p. $24-28$

Franklin, H.J. 1917. Report of the cranberry substation for 1916. Massachusetts Expt. Sta. Bul. 180. p. $218-221$.

Roper, T.R. 1994. Sanding: Our current understanding. Wisconsin Cranberry School Proc., Stevens Point. 5:38-43.

Roper, T.R., et al. 1993. Fruiting of cranberry uprights reduces fruiting the following year. HortScience 28:228.

Sapers, G.M. and D.L. Hargrave. 1987. Proportions of individual anthocyanins in fruits of cranberry cultivars. J. Amer. Soc. Hort. Sci. 112:100-104.

SAS Institute. 1988. SAS-STAT guide for personal computers, 6th ed. SAS Inst., Cary, N.C.

Strik, B.C. and A.P. Poole. 1992. Alternate-year pruning recommended for cranberry. HortScience 27:1327.

Strik, B.C., T.R. Roper, C.J. DeMoranville, J.R Davenport, and A.P. Poole. 1991. Cultivar and growing region influence return bloom of cranberry uprights. HortScience 26:1366-1367.

Tomlinson, B. 1937. Proper sanding of great importance in good bog management. Cranberries Mag. 1:4, 8-11. 